\title{
Evaluation of knowledge and attitude of pregnant women about double and triple tests performed in a university hospital
}

\author{
Bir üniversite hastanesine başvuran gebelerin ikili ve üçlü tarama testleri \\ hakkındaki bilgi ve tutumlarının değerlendirilmesi
}

\author{
Çiğdem KUNT işGÜDER ${ }^{1}$, Hatice YILMAZ DOĞRU ${ }^{1}$, Asker Zeki ÖZSOY ${ }^{1}$, Yunus Emre BULUT², Nursah BAŞOL ${ }^{3}$
}

\begin{abstract}
Double and triple tests performed during pregnancy are highly important in order to determine risk of fetal aneuploidy. Our aim in this study is to evaluate the knowledge level of the pregnant women regarding these screening tests. The study population consisted of 354 pregnant patients who applied to outpatient clinic of Gynecology and Obstetrics Department of Gaziosmanpaşa University Faculty of Medicine between October-December 2015 within their 11. and 24. gestational weeks to undergo their routine follow-ups. Research data were collected through a questionnaire form and the chi-square test was utilized for statistical analysis. $P<0.05$ was accepted as the level of significance. The mean age of the pregnant women $(n=354)$ who participated in the study was $26.71 \pm 5.56$ (16-43 yrs)years, and the mean gestational week at admission was $14.45 \pm 2.91$ (10-24 wks) weeks. All of the participants declared that they had or would undergone screening tests, while majority (58.8\%) of the study participants thought that it was obligatory to undergo screening tests. However, patients with at least lycée education and those who worked answered the questions statistically significantly more correctly $(p<0.05)$. It was found out that higher the educational level of the pregnant women was, higher the level of knowledge they had about the tests. In addition to increasing the educational levels of pregnant women in general, it is necessary that physicians should spare adequate time for informing pregnant women efficiently, and correctly in order to apply the screening tests effectively.
\end{abstract}

Keywords: Double screening, triple screening, knowledge level of pregnant women

\begin{abstract}
Öz
Gebelikte yapılan ikili ve/veya üçlü tarama testleri fetal anöploidi riskini belirlenmesi açısından çok önemlidir. Bu çalışmadaki amacımız, gebelerin bu tarama testleri hakkında bilgi düzeylerini değerlendirmektir. Çalışmanın evrenini Gaziosmanpaşa Üniversitesi Tıp Fakültesi Hastanesi Kadın Hastalıkları ve Doğum Polikliniklerine Ekim-Aralık 2015 tarihleri arasında rutin takiplerini yaptırmak için başvuran 11-24 haftalık 354 gebe oluşturdu. Araştırma verileri anket formu aracılığıyla toplandı ve istatistik hesaplamalarda ki-kare (X2) testi kullanıldı. Istatistiksel anlamlıIık düzeyi $p<0,05$ olarak kabul edildi. Çalışmaya katılan gebelerin

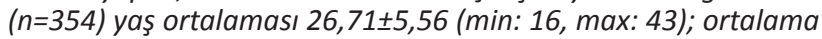
gebelik haftası 14,45 $\pm 2,91$ (min: 10, maks: 24)'di. Katılımcıların tamamı (\%100) tarama testlerini yaptırdığını ya da yaptıracağını söylemekte iken, \%58,8'i tarama testlerinin yapılmasının zorunlu olduğunu düşünmekteydi. Gebelerin tarama testleri ile ilgili verdikleri yanıtlar, gebelerin eğitim ve çalışma durumları açısından incelendiğinde lise ve üzeri okul mezunu ve çalışan gebelerin doğru cevap verme oranlarının diğerlerine göre istatistiksel olarak anlamlı şekilde daha yüksek olduğu bulundu $(p<0,05)$. Gebelerin eğitim düzeyleri arttıkça tarama testleri hakkında bilgi düzeylerinin arttığı belirlenmiştir. Tarama testlerinin etkin bir şekilde uygulanması için eğitim düzeylerinin iyileştirilmesinin yanında, hekimlerin gebelere yeterli zaman ayırarak etkili ve doğru bir bilgilendirme yapması da gerekmektedir.
\end{abstract}

Anahtar kelimeler: Ikili tarama, üçlü tarama, gebe bilgi düzeyi

\section{INTRODUCTION}

It is a bliss to have a normal course of pregnancy and then deliver a healthy baby for mother-to-be and the family. The regular controls and screening tests are helpful to diagnose the possible problems at an early stage in pregnancy and to predict high-risk pregnancy ${ }^{1}$. It is medically more difficult to abort a fetus with detected chromosomal abnormalities in advancing weeks of pregnancy. For this reason, scre-

Received: 08.06.2017

Accepted: 30.10 .2017

${ }^{1}$ Department of Obstetrics and Gynecology, Gaziosmanpaşa University School of Medicine, Tokat, Turkey

${ }^{2}$ Bitlis Public Health Directorate, Bitlis, Turkey

${ }^{3}$ Department of Emergency Medicine, Gaziosmanpaşa University School of Medicine, Tokat, Turkey

Yazışma adresi: Cigdem Kunt İsguder, Department of Obstetrics and Gynecology, Gaziosmanpaşa University School of Medicine, Tokat, Turkey

e-mail: cidos_55@hotmail.com 
ening tests with reliable results should be performed at an early stage in pregnancy. We aimed to identify an anomalous baby at an early stage with the help of the combined screening tests (weeks 11-14), the triple screening tests (weeks 15-20), noninvasive advanced ultrasonographic examination and invasive tests such as chorionic villus sampling (CVS) or amniocentesis. The advancements in biochemical markers and imaging technologies have enabled us to detect fetal chromosomal abnormalities in the early weeks of pregnancy ${ }^{2-4}$.

Screening studies about Down Syndrome have demonstrated that the prior knowledge of pregnant women about the tests was important in decisionmaking about proceeding with the tests ${ }^{5,6}$. While incomplete or incorrect information lead the pregnant women to refuse the screening, and even diagnostic tests when necessary ${ }^{7,8}$, redundant information results in confusion and drawback during the implementation of the tests ${ }^{9,10}$. Some studies have shown that the pregnant women prefer the first trimester screening tests over second trimester tests owing to the possibility of early detection of fetal anomalies and termination of pregnancy at the beginning ${ }^{11,12}$. The choice of test depends on the obstetric assessment protocols of the region or country, and on the demographical and sociocultural features of the women ${ }^{12,13}$.

This study was planned to evaluate the pregnant women's knowledge, thoughts and attitudes about noninvasive tests used for the detection of fetal chromosomal abnormality risk in the first and second trimesters of pregnancy. Since the study was performed in a university hospital and the region (Tokat province) has a strong demographical variety in structure, as an important fact pregnant women from various economic and cultural levels were involved in the study. The factors motivating us to make this study included the presence of misunderstanding (e.g. the tests are obligatory), prejudices, lack of proper information, and unnecessary concerns about the risky results with regard to the routine screening tests in pregnant women who applied to our outpatient clinic.

\section{MATERIALS and METHODS}

This cross-sectional study that was approved by the Institutional Review Board and Ethical Committee of Gaziosmanpasa University Hospital (17-KAEK-107) encompassed 4800 pregnant women who applied to outpatient clinics of Gynecology and Obstetrics Department, Gaziosmanpaşa University Faculty of Medicine for pregnancy monitoring between October and December 2015. Sample size was estimated as 356 based on Epi Info 7 statistics program, while accepting the unknown prevalence (p) as $50 \%$ and deviation (d) as 0.05 , within $95 \%$ confidence interval, pattern effect was accepted to be 1 . The study was completed with 354 randomly-chosen pregnant women who free-willingly participated in the study. They were requested to fill a questionnaire form prepared according to the recent literature. The form included 8 questions aimed to elucidate their level of knowledge and attitude about double and triple screening tests as well as their sociodemographic features.

\section{Statistical analysis}

The data were evaluated using SPSS 18.0 package software. Specifications were expressed as numbers, percentages, mean and standard deviation. Intergroup differences were evaluated using chi-square test. Level of statistical significance was accepted to be $p<0.05$.

Table 1. Socio-demographic features of the pregnant women who took part in the study.

\begin{tabular}{llll}
\hline Features & & $\mathbf{n}$ & $\%$ \\
\hline Age Group & Under 25 & 139 & 39.3 \\
& $25-34$ & 180 & 50.8 \\
\multirow{2}{*}{ Employment Status } & W5 and older & 35 & 9.9 \\
& Working & 62 & 17.5 \\
Social Security & Housewife & 292 & 82.5 \\
& There is none & 43 & 12.1 \\
Income Status & There is & 311 & 87.9 \\
& Minimum wage and below & 224 & 63.3 \\
Educational Status & Above minimum wage & 130 & 36.7 \\
& Primary/Secondary school & 224 & 63.3 \\
Total & High School and above & 130 & 36.7 \\
& & 354 & 100.0
\end{tabular}




\section{RESULTS}

The mean age of the women was $26.71 \pm 5.56$ ( $\min : 16$, max:43) years, and the mean gestational week at admission was $14.45 \pm 2.91$ months (min:10, max:24). Majority $(82.5 \%)$ of the participants were housewives, and $63.3 \%$ of the families had a monthly income at a level of or below the minimum wage announced by the goverment in 2015. A small percentage (12.1\%) of them had no social security. Most patients were primary/secondary school graduates (63.3\%) while $36.7 \%$ of them were at least high school or university graduates (Table 1 ).

Table 2. The distribution of the responses given by the pregnant women who took part in the survey study to the questions about double/triple tests according to their educational status.

\begin{tabular}{|c|c|c|c|c|c|c|c|c|c|}
\hline \multirow[b]{3}{*}{$\begin{array}{l}\text { Questions about double/triple } \\
\text { screening tests }\end{array}$} & & \multicolumn{8}{|c|}{ Educational status of pregnant women } \\
\hline & & \multicolumn{2}{|c|}{$\begin{array}{l}\text { Primary/ } \\
\text { secondary } \\
\text { School } \\
\text { graduates } \\
(n=221)\end{array}$} & \multicolumn{2}{|c|}{$\begin{array}{l}\text { At least } \\
\text { high } \\
\text { school } \\
\text { graduates } \\
\text { (n=133) }\end{array}$} & \multicolumn{2}{|c|}{$\begin{array}{c}\text { Total } \\
(n=354)\end{array}$} & \multirow[b]{2}{*}{$\chi^{2}$} & \multirow[b]{2}{*}{$\mathrm{p}$} \\
\hline & & $\mathrm{n}$ & $\%$ & $\mathrm{n}$ & $\%$ & $\mathrm{n}$ & $\%$ & & \\
\hline \multirow{4}{*}{$\begin{array}{l}\text { How did the pregnant women learn } \\
\text { about the tests? }\end{array}$} & Physician's advice & 202 & 91.4 & 110 & 82.7 & 312 & 88.1 & 6.459 & 0.091 \\
\hline & Internet & 8 & 3.6 & 11 & 8.3 & 19 & 5.4 & & \\
\hline & Friend's advice & 10 & 4.5 & 10 & 7.5 & 20 & 5.6 & & \\
\hline & Television/Newspaper & 1 & 0.5 & 2 & 1.5 & 3 & 0.8 & & \\
\hline \multirow[t]{3}{*}{$\begin{array}{l}\text { What is the purpose of taking the } \\
\text { tests? }\end{array}$} & $\begin{array}{l}\text { Detecting the physical } \\
\text { disability risk of the baby }\end{array}$ & 70 & 31.7 & 30 & 22.6 & 100 & 28.2 & 29.796 & $<0.001$ \\
\hline & $\begin{array}{l}\text { Detecting the risk of Down } \\
\text { Syndrome and other anomalies* }\end{array}$ & 87 & 39.3 & 90 & 67.7 & 177 & 50.0 & & \\
\hline & I don’t know/I have no idea & 64 & 29.0 & 13 & 9.7 & 77 & 21.8 & & \\
\hline \multirow[t]{2}{*}{ Is it obligatory to take the tests? } & Yes & 150 & 67.9 & 58 & 43.6 & 208 & 58.8 & 20.173 & $<0.001$ \\
\hline & No & 71 & 32.1 & 75 & 56.4 & 146 & 41.2 & & \\
\hline \multirow[t]{2}{*}{ Are these tests safe? } & Yes & 176 & 79.6 & 78 & 58.6 & 254 & 71.8 & 18.051 & $<0.001$ \\
\hline & No & 45 & 20.4 & 55 & 41.4 & 100 & 28.2 & & \\
\hline \multirow{2}{*}{$\begin{array}{l}\text { Will the baby be absolutely disabled } \\
\text { if the risky results are obtained? }\end{array}$} & It will definitely be disabled & 63 & 28.5 & 22 & 16.5 & 85 & 24.0 & 5.876 & 0.015 \\
\hline & It may not be disabled & 158 & 71.5 & 111 & 83.5 & 269 & 76.0 & & \\
\hline \multirow{2}{*}{$\begin{array}{l}\text { Will the baby absolutely healthy if } \\
\text { the results are not risky? }\end{array}$} & It will definitely be healthy & 89 & 40.3 & 25 & 18.8 & 114 & 32.2 & 17.538 & $<0.001$ \\
\hline & It may not be healthy & 132 & 59.7 & 108 & 81.2 & 240 & 67.8 & & \\
\hline \multirow{3}{*}{$\begin{array}{l}\text { What should be done if risky results } \\
\text { are obtained? }\end{array}$} & $\begin{array}{l}\text { Delivery should be deferred } \\
\text { without doing anything }\end{array}$ & 153 & 69.2 & 73 & 37.6 & 226 & 63.8 & 16.837 & $<0.001$ \\
\hline & $\begin{array}{l}\text { Amniocentesis should be } \\
\text { performed* }\end{array}$ & 31 & 14 & 43 & 32.3 & 74 & 20.9 & & \\
\hline & Abortion should be performed & 37 & 16.7 & 17 & 12.8 & 54 & 15.3 & & \\
\hline \multirow{2}{*}{$\begin{array}{l}\text { Do you want to give birth to a } \\
\text { disabled baby? }\end{array}$} & Yes, it does not matter & 160 & 72.4 & 102 & 76.7 & 262 & 74.0 & 0.796 & 0.372 \\
\hline & No, I certainly do not & 61 & 27.6 & 31 & 23.3 & 92 & 26.0 & & \\
\hline
\end{tabular}

*The difference originates from this line. 
Table 3. The distribution of the answers of the pregnant women who took part in the study about double/triple tests according to their employment status.

\begin{tabular}{|c|c|c|c|c|c|c|c|c|c|}
\hline \multirow[b]{3}{*}{$\begin{array}{l}\text { Questions about double/triple } \\
\text { screening tests }\end{array}$} & & \multicolumn{8}{|c|}{ Educational status of pregnant women } \\
\hline & & \multicolumn{2}{|c|}{$\begin{array}{l}\text { Housewife } \\
(n=292)\end{array}$} & \multicolumn{2}{|c|}{$\begin{array}{l}\text { Working } \\
(n=62)\end{array}$} & \multicolumn{2}{|c|}{$\begin{array}{c}\text { Total } \\
(n=354)\end{array}$} & \multirow[b]{2}{*}{$\chi^{2}$} & \multirow[b]{2}{*}{$\mathrm{p}$} \\
\hline & & $\mathrm{n}$ & $\%$ & $\mathrm{n}$ & $\%$ & $\mathrm{n}$ & $\%$ & & \\
\hline \multirow{5}{*}{$\begin{array}{l}\text { How did the pregnant women learn } \\
\text { about the tests? }\end{array}$} & Physician's advice & 259 & 88.7 & 53 & 85.5 & 312 & 88.1 & 0.830 & 0.842 \\
\hline & Internet & 15 & 5.1 & 4 & 6.5 & 19 & 5.4 & & \\
\hline & Friend's advice & 16 & 5.5 & 4 & 6.5 & 20 & 5.6 & & \\
\hline & Television/Newspaper & 2 & 0.7 & 1 & 1.6 & 3 & 0.8 & & \\
\hline & $\begin{array}{l}\text { Detecting the physical } \\
\text { disability risk of the baby }\end{array}$ & 89 & 30.5 & 11 & 17.7 & 100 & 28.2 & 29.796 & $<0.001$ \\
\hline \multirow[t]{2}{*}{$\begin{array}{l}\text { What is the purpose of taking the } \\
\text { tests? }\end{array}$} & $\begin{array}{l}\text { Detecting the risk of Down } \\
\text { Syndrome and other anomalies* }\end{array}$ & 132 & 45.2 & 45 & 72.6 & 177 & 50.0 & & \\
\hline & I don't know/I have no idea & 71 & 24.3 & 6 & 9.7 & 77 & 21.8 & & \\
\hline \multirow[t]{2}{*}{ Is it obligatory to take the tests? } & Yes & 176 & 60.3 & 32 & 51.6 & 208 & 58.8 & 20.173 & $<0.001$ \\
\hline & No & 116 & 39.7 & 30 & 48.4 & 146 & 41.2 & & \\
\hline \multirow[t]{2}{*}{ Are these tests safe? } & Yes & 218 & 74.7 & 36 & 58.1 & 254 & 71.8 & 6.947 & 0.008 \\
\hline & No & 74 & 25.3 & 26 & 41.9 & 100 & 28.2 & & \\
\hline \multirow{2}{*}{$\begin{array}{l}\text { Will the baby be absolutely disabled } \\
\text { if the risky results are obtained? }\end{array}$} & It will definitely be disabled & 78 & 26.7 & 7 & 11.3 & 85 & 24.0 & 5.848 & 0.016 \\
\hline & It may not be disabled & 214 & 73.3 & 55 & 88.7 & 269 & 76.0 & & \\
\hline \multirow{2}{*}{$\begin{array}{l}\text { Will the baby absolutely healthy if } \\
\text { the results are not risky? }\end{array}$} & It will definitely be healthy & 106 & 36.3 & 8 & 12.9 & 114 & 32.2 & 11.775 & $<0.001$ \\
\hline & It may not be healthy & 186 & 63.7 & 54 & 87.1 & 240 & 67.8 & & \\
\hline \multirow[t]{3}{*}{$\begin{array}{l}\text { What should be done if risky results } \\
\text { are obtained? }\end{array}$} & $\begin{array}{l}\text { Delivery should be deferred } \\
\text { without doing anything }\end{array}$ & 197 & 67.5 & 29 & 46.8 & 226 & 63.8 & 11.378 & 0.003 \\
\hline & $\begin{array}{l}\text { Amniocentesis should be } \\
\text { performed* }\end{array}$ & 52 & 17.8 & 22 & 35.5 & 74 & 20.9 & & \\
\hline & Abortion should be performed & 43 & 14.7 & 11 & 17.7 & 54 & 15.3 & & \\
\hline \multirow{2}{*}{$\begin{array}{l}\text { Do you want to give birth to a } \\
\text { disabled baby? }\end{array}$} & Yes, it does not matter & 217 & 74.3 & 45 & 72.6 & 262 & 74.0 & 0.015 & 0.902 \\
\hline & No, I certainly do not & 75 & 25.7 & 17 & 27.4 & 92 & 26.0 & & \\
\hline
\end{tabular}

*The difference originates from this line.

More than half (58.8\%) of the participants thought that it was obligatory to take the tests. Majority $(88.1 \%)$ of them claimed that they had learnt about the tests from their physicians, while the rest of the participants stated that they were informed about the tests through their friends $(5.6 \%)$, internet $(5.4 \%)$ or media (newspapers, television etc).
Half of the participants thought that the reason to use these tests was to detect Down Syndrome and other chromosomal anomalies, while $28.2 \%$ of them thought that they were performed to find out risk of physical disability. However, $21.8 \%$ of the pregnants stated that they did not know why the tests were done.

Some (28.2\% ) participants did not find the tests reliable, 
and $36.7 \%$ of them expressed that they could repeat the tests in another center in case the test results pointed out to a risky condition.

Twenty-four percent of the women claimed that baby would be definitely disabled in case of risk, and yet $32.2 \%$ believed that baby would be definitely healthy if the results did not indicate any evidence of risk. In case of risk, most of the pregnants said that they would wait for the delivery without doing anything, and $20.9 \%$ of them believed the necessity of amniocentesis, while $15.3 \%$ of them stated that it would be necessary to have abortion. Seventy-four percent of the participants expressed that they did not want to bring a disabled baby into the world.

A statistically significant difference was detected in the distribution of responses given to the questions concerning rationale, necessity of performing screening tests, their safety, and reliability, whether risky test results absolutely signify delivery of disabled or healthy child, and measures to be taken in risky situations according to educational levels, and occupational status of the pregnants ( $p<0.05$, Tables 2 , and 3). Lycée, and higher education graduate pregnants, and working pregnants responded accurately to statistically significantly greater number of questions $(p<0.05$, Tablo 2 , Tablo 3). However when responses of pregnants to screening test questions were analyzed based on the presence or absence of social security coverage, any statistically significant difference was not detected between groups ( $p>0.05)$.

\section{DISCUSSION}

The higher the educational level, the more correct were the answers and the working women had given more aproppriate answers regarding these screening tests in this study. A study by Ergün et al. ${ }^{14}$, showed similar results in that knowledge level of the patients increased in parallel with their education level. Similarly, Jaques et al. ${ }^{15}$ detected a positive correlation between the education levels of pregnant women and their level of knowledge about screening tests. Results of both studies correlated with those of our study.
In the study by Gekas et al. ${ }^{16} 41.5 \%$ of the pregnants had been told that the screening tests were obligatory which led them to feel themselves under pressure about the tests. In our study the participants also thought that the tests were obligatory. Physicians' neglect in providing the pregnant women with adequate information about these voluntary screening tests may explain this misunderstanding. Besides, physicians should tell the pregnants that they had their right to reject screening tests. The putative reason might be the physician's concern about facing a judicial problem in case of undetected fetal aneuploidy. However, it has been shown that, pregant women comprehend the importance of the screening tests and their idle worries are quelled when their physicians inform them properly ${ }^{17}$.

According to Gourounti et al. ${ }^{18}$, the pregnants should be given enough time in the decision-making process about screening tests, diagnostic tests, and termination of their pregnancies. Undoubtedly, adequate time and suitable conditions are required in order to inform them, however it may not be always possible to spare time for providing information. When the prenatal screening tests yielded highly risky results for fetal aneuploidy, the patient, and the physician have difficulty in managing this condition. The physicians generally offer the pregnant women application of invasive tests so as to evade the consequences of litigation. In a study performed by Karakuş et al. ${ }^{19}$ the authors found that $68.5 \%$ of the pregnants who had highly risky prenatal screening test results had consented to undergo amniocentesis. In our study we determined the corresponding rate as 20.9 percent. We thought that our lower rate is related to our leaving the pregnant women free in their decisions.

Besides, Stefansdottir et al. ${ }^{20}$ showed that those with a history of fetal congenital anomaly and fetal aneuploidy had a higher level of willingness to undergo these screening tests. In our study, antenatal pathologies of the pregnants such as congenital anomalies were not investigated, so we couldn't determine significance of their impact on decision-making process. Although majority of the participants declared that they did not 
want to have a disabled baby, they stated that they would choose to continue the pregnancy with no further diagnostic tests if favourable results could be obtained. The factors contributing to this contradiction were not investigated in this study, so any conclusive comments could not be made. However, in a study by Alsulaiman et al. ${ }^{21}$ it was shown that the spiritual values and beliefs of the families play an important role in the decision-making process for taking screening tests and the termination of pregancy.

In conclusion, screening tests that are used to detect the risk of fetal aneuploidy are very important both for the physicians and the pregnant women. It is possible to detect fetal aneuploidy in early gestational weeks with the help of improvements in the fields of screening and biochemistry. This approach may help to avoid confusion and idle worries of pregnants, and increase their participation in the tests, if physicians inform the pregnant women properly, relieve their concerns arising from misinformation, and present options about possible test results. Apart from that, it is necessary to increase the education level of the society, to form a national policy for application of screening tests, to plan counselling for them related to screening tests and to provide necessary conditions during the counselling.

\section{REFERENCES}

1. Diribaş K, Kaya C, Koç FA. Illk Trimester Fetal Tarama Testleri. Türkiye Klinikleri Jinekoloji Obstetrik Dergisi 2002;2:186-91.

2. Alldred SK, Takwoingi Y, Guo B, et al. First trimester serum tests for Down's syndrome screening. Cochrane Database Syst Rev 2015;30:CD011975.

3. Cicero S, Spencer K, Avgidou K, et al. Maternal serum biochemistry at $11-13(+6)$ weeks in relation to the presence or absence of the fetal nasal bone on ultrasonography in chromosomally abnormal fetuses: an updated analysis of integrated ultrasound and biochemical screening. Prenat Diagn 2005;25:977-983.

https://doi.org/10.1002/pd.1211

4. Malone FD, Canick JA, Ball RH, et al. First-trimester or secondtrimester screening, or both, for Down's syndrome. N Engl J Med 2005;353:2001-2011. https://doi.org/10.1056/NEJMoa043693

5. Brajenović-Milić B, Babić l, Ristić S, et al. Pregnant women's attitudes toward amniocentesis before receiving Down syndrome screening results. Womens Health Issues 2008;18:79-84. https://doi.org/10.1016/j.whi.2007.10.003

6. Spencer K, Aitken D. Factors affecting women's preference for type of prenatal screening test for chromosomal anomalies. Ultrasound Obstet Gynecol 2004;24:735-9. https://doi.org/10.1002/uog.1768

7. Marteau Tm, Johnson M, Kidd J, et al. Psychological Models In Predicting Uptake Of Prenatal Screening. Psychol Health 1992;6:13-22. https://doi.org/10.1080/08870449208402017

8. Pruksanusak N, Suwanrath C, Kor-Anantakul O, et al. A survey of the knowledge and attitudes of pregnant Thai women towards Down syndrome screening. J Obstet Gynaecol Res 2009;35:876-881. https://doi.org/10.1111/j.1447-0756.2009.01035.x

9. Nagle C, Gunn J, Bell R, et al. Use of a decision aid for prenatal testing of fetal abnormalities to improve women's informed decision making: a cluster randomised controlled trial [ISRCTN22532458]. BJOG 2008;115:339-347. https://doi.org/10.1111/j.1471-0528.2007.01576.x

10. Reid B, Sinclair M, Barr O, et al. A meta-synthesis of pregnant women's decision-making processes with regard to antenatal screening for Down syndrome. Soc Sci Med 2009;69:1561-1573. https://doi.org/10.1016/j.socscimed.2009.09.006

11. Mulvey S, Wallace EM. Women's knowledge of and attitudes to first and second trimester screening for Down's syndrome. BJOG 2000;107:1302-1305. https://doi.org/10.1111/j.1471-0528.2000.tb11624.x

12. Müller MA, Bleker OP, Bonsel GJ, Bilardo CM. Women's opinions on the offer and use of nuchal translucency screening for Down syndrome. Prenat Diagn 2006;26:105-111. https://doi.org/10.1002/pd.1344

13. Gourounti K, Lykeridou K, Daskalakis G, et al. Women's perception of information and experiences of nuchal translucency screening in Greece. Fetal Diagn Ther 2008;24:86-91. https://doi.org/10.1159/000142133

14. Ergün P, Köken G, Coşar E, et al. Gebelerin Üçlü Tarama Testi ve Gebelikte Yapılan Diğer Testler Hakkındaki Bilgi Düzeyinin Ölçülmesi. TAF Prev Med Bull 2011;10:403-408.

15. Jaques AM, Sheffield LJ, Halliday JL. Informed choice in women attending private clinics to undergo first-trimester screening for Down syndrome. Prenat Diagn 2005;25:656-664. https://doi.org/10.1002/pd.1218

16. Gekas J, Gondry J, Mazur S, et al. Informed consent to serum screening for down syndrome: Are women given adequate information? Prenat Diagn 1999;19:1-7.

17. Bramwell R, Carter D. An exploration of midwives' and obstetricians' knowledge of genetic screening in pregnancy and their perception of appropriate counselling. Midwifery 2001;17:133-141. https://doi.org/10.1054/midw.2000.0243

18. Gourounti K, Sandall J. Do pregnant women in Greece make informed choices about antenatal screening for Down's syndrome? A questionnaire survey. Midwifery 2008;24:153-162. https://doi.org/10.1016/j.midw.2006.09.001

19. Karakuş R. The Research of Knowledge Level About Double or Triple Tests of Pregnant. Jinekoloji - Obstetrik ve Neonatoloji Tıp Dergisi 2015;12:174-178.

20. Stefansdottir V, Skirton H, Jonasson K, et al. Effects of knowledge, education, and experience on acceptance of first trimester screening for chromosomal anomalies. Acta Obstet Gynecol Scand 2010;89:931-938. https://doi.org/10.3109/00016341003686073

21. Alsulaiman A, Mousa A, Kondkar AA, et al. Attitudes of Saudi parents with a deaf child towards prenatal diagnosis and termination of pregnancy. Prenat Diagn 2014;34:153-158. https://doi.org/10.1002/pd.4273 